\title{
Of "Old" and "New" Housewives: Everyday Housework and the Limits of Household Rationalization in the Urban Working-Class Milieu of the Weimar Republic
}

\author{
KAREN HAGEMANN
}

\begin{abstract}
Summary: The paper centers on the question of how widespread was the impact of the lively discussion of housing and household reform during the Weimar Republic. Therefore the focus is on the experiences of working-class women. Against the background of material conditions in proletarian households, it analyzes which norms and standards concretely shaped working women's everyday housework in the urban working-class milieu in the 1920s, and how these norms and standards arose. The paper demonstrates the substantial reservations and resistance with which even better-off working women approached all efforts at rationalizing their housework in the 1920 s. They wanted better living conditions and new household appliances, but the vast majority could not afford both. The specific norms and standards against which a "good" housewife was measured, norms and standards which corresponded more to the "old" model of the "economical, clean and tidy" housewife, also blocked acceptance, however.
\end{abstract}

We women may surely take pride in how quickly great improvements have been made in the field of household rationalization. But if we pose the question to what extent the blessings of household rationalization have benefitted the broad masses, the answer to which is essential for judging the significance of all innovations in this arena, we do not have so much to be proud of. The circles of society to which the new ideas have penetrated thus far are still extremely narrow, and far too few women have any inclination to apply these principles in their own homes.

In March 1929, this critical assessment appeared under the heading "Rationalization in Workers' Households" in the Hamburger Echo, a regional daily of the German Social Democratic Party (SPD). In the final years of the Weimar Republic, Social Democratic newspapers and journals increasingly lamented the failure of efforts at household rational-

* I would like to thank Pamela Selwyn for her translation.

1 "Rationalisierung des Arbeiterhaushalts", Hamburger Echo (hereafter HE), 76, 17 March 1929. 
ization to gain wide influence. ${ }^{2}$ Since the early 1920 s, the SPD women's organization had been advocating housing reform and a "rationalization of the individual household". It had been a focus of Social Democratic women's activities ever since the national women's conference in Kiel in May 1927, where the subject was discussed intensely. ${ }^{3}$ Demands for household rationalization were even more popular in the middle-class women's movement. The large and numerous middle-class housewives' associations, in particular, which belonged to the umbrella organizations Reichsverband Deutscher Hausfrauenvereine (National Federation of German Housewives' Associations) and the Reichsverband landivirtschaftlicher Hausfrautenvereine (National Federation of Rural Housewives' Associations) advocated a "professionalization of housework" through a reform of "household management"."

2 Cf. e.g. "Rationalisierter Einzelhaushalt oder GroBhaushalt", Die Genossin (hereafter Ge.), 4 (April 1927), pp. 127ff.; "Neue Hauswirtschaft", Gewerkschaftliche Frauenzeitung (hereafter GF), 5 (May 1929), p. 40.

${ }^{3}$ For more detail, see Karen Hagemann, Frauenalltag und Mä̈nnerpolitik. Alltagsleben und gesellschaftliches Handeln von Arbeirefrauen in der Weimarer Republik (Bonn, 1990), pp. 106-114. On the Social Democratic women's movement in the Weimar Republic more generally, see ibid., pp. 509-638; Hagemann, "'Equal but not the same': The Social Democratic Women's Movement in the Weimar Republic", in Roger Fletcher (ed.), Bermstein to Brandr: A Short History of German Social Democracy (London, 1987), pp. 133-143, and "Men's Demonstrations and Women's Protest: Gender in Collective Action in the Urban Working-Class Milieu during the Weimar Republic", Gender and History, 5 (1993), pp. 101-119; and "La 'question des femmes' et les rapport masculinféminin dans la social-démocratie allemande sous la République Weimar", Le Mouvement Social 163 (April-June 1993), pp. 25-44; Renate Pore, A Conflict of Interest: Women in German Social Democracy (Westport, 1981); Werner Thönnessen, The Emancipation of Women: The Rise and Decline of the Women's Movement in German Social Democracy 1863-1933 (London, 1973).

‘Cf. e.g. Mary Nolan, “'Housework Made Easy': The Taylorized Housewife in Weimar Germany's Rationalized Economy", Feminist Studies 16 (1990), pp. 549-577; Barbara Orland, "Emanzipation durch Rationalisienung? Der 'rationelle Haushalt' als Konzept institutionalisierter Frauenpolitik in der Weimarer Republik", in Dagmar Recse et al., Rationale Beziehungen? Geschlechterverhälnisse im Rationalisienungsprozeß (Frankfurt a. Main, 1993), pp. 222-250 and "Effiziens im Heim: Die Rationalisierungsdebatte zur Reform der Hausarbeit in der Weimarer Republik", Kulur und Technik 7, (1983), 4, pp. 221-227; Carola Sachse, "Anfange der Rationalisierung der Hausarbeit in der Weimarer Republik", in Barbara Orland (ed.), Haushalts Träume: Ein Jahrhundert Technisierung und Rationalisienang im Haushalt, published by the Arbeitsgemeinschaft Hauswirtschaft e.V. and Stiftung Verbraucherinstitut (Konigstein i. Taunus, 1990), pp. 49-61; Hiltraud Schmidt-Waldherr, "Rationalisierung der Hausarbeit in den zwanziger Jahren", in Gerda Tomieporth (ed.), Arbeitsplatz Haushalt. Zur Theorie und Okologie der Hausarbeit (Berlin, 1988), pp. 32-54. On the middle-class women's movement, see Renate Bridenthal, "'Professional' Housewives: Stepsisters of the Women's Movement", in Renate Bridenthal et al., When Biology Became Destiny: Women in Weimar and Nazi Germany (New York, 1984), pp. 153-173 and "Class Struggle Around the Hearth: Women and Domestic Service in the Weimar Republic", in Michael Dobowski and Isidor Wallisman (eds), Towards the Holocaust: Anti-Semitism and Fascism in Weimar Germany (Westport, CT, 1983), pp. 243264: Hiltraud Schmidt-Waldherr, Emanzipation durch Professionalisierung: Politische Stra- 
The idea of a "rationalization of housework", which originated in the USA, began to receive attention in Germany in the early 1920s and, in the context of the Weimar discourse on the "rationalization" of broad segments of society and the economy, ${ }^{6}$ rapidly gained in popularity." What was being propagated here was no longer the pre-war model of the tirelessly bustling housewife who tended her household with "frugality, cleanliness and order", but rather that of a housewife who "did her work and handled the household finances rationally", and who knew how to save not only money and material, but also her own time and energy. According to the protagonists of housing and household reform,

tegien und Konflikte der bürgerlichen Frauenbewegung während der Weimarer Republik und die Reaktion des burgerlichen Antifeminismus und des Nationalsozialismus (Frankfurt a. Main, 1987), pp, 176-187. On the German middle-class women's movement more generally, see for example Richard J. Evans, The Feminist Movement in Germany, 1894 1933 (Beverly Hills, 1976); Ute Frever, Women in German History: From Bourgeois Emancipation to Sexual Liberation (Oxford, 1989), pp. 168-204; Barbara Greven-Aschoff, Die burgerliche Frauenbewegung in Deutschland 1894-1933 (Göttingen, 1981).

${ }^{3}$ The best-known American figures were Christine Frederick and Lilian M. Gilbreth, whose writings were widely read in Germany as well. See Christine Frederick, Die rationelle Haushaltsfuhrung: Betriebswissenschaftliche Studien (Berlin, 1921); Lilian M. Gilbreth, Heim und Arbeit: Die Lebensaufgabe der modemen Hausfrau (Stuttgart, 1930). For the USA, see: Gisela Bock and Barbara Duden, "Arbeit aus Liebe - Liebe als Arbeit: Zur Entstehung der Hausarbeit im Kapitalismus", Frauen und Wissenschaft. Beiträge zur Berliner Sommeruniversität für Frauen, Juli 1976 (Berlin, 1977), pp. 118-199; Ruth Schwartz Cowan, More Work for Mothers: The Ironies of Household Technology from the Open Hearth to the Microwave (New York, 1983), Pp. 151-192. A general overview of the American discourse about domesticity is given by Glenna Matthews, Just a Housewife. The Rise and Fall of Domesticity in the United States (Oxford and New York, 1987). For the development of household and family life and the importance of differences by class and race, see Steven Mintz and Susan Kellog, Domestic Revolutions: A Social History of American Family Life (New York, 1988). For an overview of the international dimensions of the household rationalization movement, which, however, concentrates on household technology, see Sigfried Giedion, Mechanization Takes Command (New York, 1948). - For the general appeal of rationalization, see Charles Maier, "Between Taylorism and Technocracy: European Ideologies and the Vision of Industrial Productivity in the 1920s", Journal of Contemporary History, 8 (April 1970), pp. 27-61; Mary Nolan, Visions of Modernity. American Business and the Modemization of Germany (New York and Oxford, 1993).

7 The most famous German propagandists for household rationalization were the architect Bruno Taut, with his Die neue IVohnung (New Housing), first published in 1924, and the home economist Ema Meyer, whose book Der neue Haushall (The New Household) was to become the most important work of the German rationalization movement, going through thirty-seven editions in the three years after its first appearance in 1926. See Erna Meyer, Der neue Haushalt: Ein Wegweiser zur wirtschafilichen Haushaltsführung (Stuttgart, 1926); substantially augmented and revised edition (Stuttgart, 1929); Bruno Taut, Die neue Wohnung: Die Frau als Schöpferin (Leipzig, 1924). On the objectives of the German movement for household rationalization, see the literature in notes 3 and 4; on the model of the housewife more generally, see Anabella Weismann, Froh erfulle Deine Pflicht: Die Entwicklung des Hausfrauenleitbildes im Spiegel trivaler Massenmedien in der Zeit zwischen Reichsgrïndung und Weltwirtschaftskrise (Berlin, 1988). 
it was no longer enough for housework to conform to the standards of social hygiene and to be performed with the greatest of thrift and efficiency under conditions of scarce material resources. They now expected housewives to regard their households as "efficiently-managed home businesses" run according to the principles of scientific management. Their chief objective should be to save time and energy in the household. A "scientifically based", more "rational" way of working was the main recommendation to help them achieve this goal. All household tasks were to be thought through and planned from the perspective of labor efficiency and economics, and home furnishings were to be "cleared out" and modernized along functional lines. The purchase of labor- and time-saving small and large kitchen appliances as well as modern household technology was only a secondary recommendation. After all, most proponents of household rationalization realized that only a small portion of households could afford such purchases. The time and labor women saved in this way should be spent on the physical and mental well-being of their families. Women were urged above all to devote more attention to the care and upbringing of their children. This shift of emphasis, it was argued, corresponded to the changing demands society made on women's work for household and family. Thus Neuzeitliche Hatswirtschafislehre [Modern Home Economics], which was published in 1928 for home economics instruction by Erna Meyer, the most important German propagandist of household rationalization, stated:

The training of our wives and mothers [is] of crucial importance for the future of our people as a whole [.. .] Only very slowly is recognition spreading that only in the efficiently managed home business can woman truly fulfill her appointed duty. After all, only such rationalization can prevent her sinking into the role of a put-upon Cinderella, and only through it can woman once again, despite the daily-growing struggle for existence, become what she once was: the preserver and inspirer of spiritual values - and the healthy reconstruction of our society is intimately bound up with this. Under today's circumstances, only when the full significance of the economic principle takes hold for consumption as it has for production, and when we help to realize it in the areas of health care, clothing, nutrition, housing and [household] management, will it be possible to save housewives and mothers time and physical labor, which is an .urgent precondition for the fulfillment of their true duty and thus for the perpetuation of the strength and health of the nation. ${ }^{8}$ (emphasis in the original)

Bourgeois women proponents of household rationalization like Erna Meyer thus regarded it primarily as a means to what they considered the necessary "modernization" and "professionalization" of household and family work. Their main concern was to stabilize, as a pillar of the

- Erna Meyer (ed.), Neuzeilliche Hauswirtschaftslehre. Handbuch zum Ausbau des hauswirtschaftlichen Unterrichts (Stuttgart, 1928, 3rd ed.), p. 5. 
existing system, the institution of the family, which they believed to be in the grip of a dangerous "crisis". At the same time they also hoped to achieve greater social recognition for housework.

The Social Democratic women advocates of household rationalization pursued farther-reaching goals. They regarded the "rationalized individual household" as a first step on the road to an all-encompassing reform of housing conditions and of the household by means of "cooperative communal households". By this they meant a centralization of all significant aspects of housekeeping, which would free "proletarian housewives" from most of their onerous labor. They saw household rationalization as a means of quickly reducing the burdens of housework for the individual working-class woman, so that she might not only better combine paid employment with her domestic and familial duties, but also have time for a social life. Demands for individual housing and household reform, which centered on suggestions for "clearing out" and "modernizing" existing furnishings, were supplemented by support for cooperative and municipal "institutions to supplement housing" as preliminary stages on the road to the long-term goal of "cooperative communal households": laundry rooms and cafeterias, nursery schools, kindergartens and after-school facilities, youth and community centers as well as playgrounds, sports facilities and parks were to be established in sufficient numbers in all city neighborhoods. ${ }^{10}$

Many Social Democratic women functionaries, but more especially representatives of the bourgeois women's movement, had high hopes for the campaign "to reform how we live" and "rationalize housework", and they were bolstered by a broad front of mainly male "modernizers: architects and urban planners, industrialists and union leaders, population and social policymakers". " During the Weimar Republic, however, the

'See Marie Baum, Familienfürsorge (Karlsruhe, 1927) and "Die Familie in Sozial- und Fürsorgepolitik der Gegenwart", Sozjale Praxis (hereafter SP), 27 (1932), cols 828ff.; Friedrich Zahn, "Familienpolitik", SP, 45 (1927), cols 1116ff.; Hagemann, Frauenallag, pp. 99 ff.

${ }^{10}$ Hertha Kraus, "Wohnungsnot und Wohnungsreform", lecture given at the SPD National Women's Conference in Kiel, in Sozialdemokratischer Parteitag 1927 in Kiel. Protokoll mit dem Bericht v. d. Frauenkonferenz, (Kiel, 1927; rpt Glashütten i. Taunus, 1974), pp. 345-355; see also pp. 355-369. For a detailed account of the development of Social Democratic positions on housing and household reform since the turn of the century, and of the controversies involved, see Hagemann, Frauenalltag, esp. pp. 106-114. Until now the literature has not produced a thorough analysis. Mary Nolan's essay "Housework Made Easy" (see note 4) also pays only scant attention to the subject.

$"$ See Nolan, "Housework"; Heinz Hirdina, "Rationalisierte Hausarbeit: Die Kuche im Neuen Bauen", Jahrbuch für Volkskunde und Kulturgeschichte, 26 (new series, vol. 11) (1988), pp. 44-80; Adelheid v. Saldern, "'Statt Kathedralen die Wohnmaschine': Paradoxien der Rationalisierung im Kontext der Moderne", in Frank Bajohr, Werner Johe and Uwe Lohalm (eds), Zivilisation und Barbarei (Hamburg, 1991), pp. 168-192; "Sozialdemokratie und kommunale Wohnungsbaupolitik in den 20er Jahren - am Beispiel von Hamburg und Wien", Archiv fur Sozialgeschichte (hereafter AfS), 25 (1985), pp. 183-237. 
movement's impact, particularly in working-class circles, was only a limited one.

In the following, I do not intend to analyze the intensive public discussions around housing and household reform. This discourse within the context of an emerging mass consumer society has been discussed at length in the historiography. ${ }^{12}$ Nor do I wish to examine (once again) the multitude of private initiatives and public measures in support of the ideas of household rationalization. ${ }^{13}$ What interests me most here is [a research desideratum]: the widespread effect of the discourse, particularly the power of the new model of the housewife to shape norms. Against the background of material conditions in proletarian households, I would like to investigate which norms and standards concretely shaped working women's ${ }^{14}$ everyday housework in the 1920 s, and how these norms and standards arose. My objective is to explore the possibilities for and limits to the propagated household rationalization in the everyday lives of working-class women. ${ }^{\text {is }}$

These questions can only be fruitfully addressed in the context of a regionally limited, stratum- and milieu-specific case study. I will thus focus on the better-off Social Democratic working-class milieu in Hamburg. In the 1920s, the second largest German city was the most important trade and service center in the country as well as the most important industrial site in northern Germany. Between 1919 and 1933, government policy in the city-state of Hamburg was largely made by the SPD. ${ }^{16}$ The party's large and relatively influential women's organization already made housing and household reform a focus of activity in the early 1920s."

and "Neues Wohnen: Wohnverhăltnisse und Wohnverhalten in GroBanlagen der 20er Jahre", in Axel Schildt and Amold Sywottek (eds), Massenwolmung und Eigenheim. Wohnungsbau und Wolnen in der Großstadt seit dem Ersten Weltkrieg (Frankfurt a. Main and New York, 1988), pp. 201-221.

12 On the extensive literature, see notes 4-7.

13 See Hagemann, Frauenalltag, pp. 114-132 and 204-219.

"I define as working women (Arbeiterfrauen) all women of the working class because of their fundamental dual responsibility for house and family on the one hand and paid labor on the other.

is On the history of everyday housework, see also Martin Soder, Hausarbeit und Stammischsozialismus: Arbeiterfamilie und Alltag im Deutschen Kaiserreich (Gießen, 1980), pp. 31ff.; and, most recently, Bärbel Kuhn, Haus Frauen Arbeit 1915-1965: Erinnerungen aus filnfzig Jahren Haishalsgeschichte (St Ingbert, 1994). For revealing contemporary literature see Kăthe Leichter, So leben wir l. ..J 1320 Industriearbeiterinnen berichten ilber ihr Leben (Vienna, 1932); Mein Arbeitstag - mein Wochenend: 150 Berichte von Textilarbeiterinnen, ed. Deutschen Textilarbeiterverband (Berlin, 1930) (reprint, ed. Alf Lidike, Hamburg, 1991).

${ }^{16}$ See Hagemann, Frauenalliag, pp. $13 \mathrm{ff}$.

"Ibid., pp. 109ff. and 594ff. In 1929, the women's organization of the Hamburg SPD even founded their own housewives' organization, in cooperation with the local branch of the "Arbeiterwohlfahrt" and the local consumer cooperative. The "Hauswirtschaftlichen Vereinigung", as it was called, was intended to represent the "interests of the housewives of the _working population". This organization, the first of its kind in Germany, was 
Together with leading representatives of the bourgeois women's associations organized in the Municipal Federation of Hamburg Women's Associations, leading women functionaries in the Hamburg SPD saw to it that in the 1920s Hamburg was one of the cities where the notion of household rationalization was conveyed relatively early to broad social strata of girls and women through elementary schools, vocational schools, adult education, municipal welfare services for pregnant women, infants and toddlers and home visitors. ${ }^{18}$

Accounts of personal experience are one of the few precise and relatively reliable sources for an analysis of everyday housework. ${ }^{19}$ Contemporary household advice manuals, like the tips in women's magazines and retail advertising brochures, can only tell us about the norms and standards of housework that were being propagated. For this reason, the main sources for the study, which rests on my broader research on the everyday life and social conduct of urban working women in the Weimar Republic, ${ }^{20}$ are interviews I conducted with fifty-one women from Hamburg's Social Democratic working-class milieu. ${ }^{21}$

devoted, among other things, to educating "proletarian housewives" about the possibilities for "rationalizing the individual household". See ibid., pp. $136 f f$.

18 Ibid., pp. 114-132 and 204-219; Karen Hagemann and Jan Kolossa, Gleiche RecitreGleiche Pflichsen? Der Frauenkampf für "staatsbiirgerliche" Gleichberechtigung, Hamburg: Ein Bilder-Lese-Buch zu Frauenalliag und Frauenbewegung in Hamburg (Hamburg, 1990), pp. 76-98.

${ }_{19}$ Miriam A. Glucksmann, Elizabeth Roberts and Ellen Ross, who have studied, with different approaches and questions, the everyday work of British working-class mothers and housewives, also used autobiographical sources and oral history. See Miriam A. Glucksmann, "Some Do, Some Don't (But in Fact They All Do Really); Some Will, Some Won't; Some Have, Some Haven't: Women, Men, Work, and Washing Machines in Inter-War Britain", Gender and History, 7 (August 1995), pp. 275-294; Elizabeth Roberts, A Woman's Place. An Oral History of Working-Class Women 1890-1940 (Oxford and New York, 1984): Ellen Ross, Love and Toil. Motherhood in Outcast London 18701918 (Oxford and New York, 1993). For their analysis of housework in the British working-class milieu, see Roberts, A Woman's Place, pp. 125-168; Ross, Love and Toil, pp. 27-54. Ellen Ross's study, in particular, contains a large bibliography for a comparison of working-class living conditions and everyday housework. which could not be cited here, see pp. 234-243.

${ }^{\circ}$ See Hagemann, Frauenalltag, and "Wir hatten mehr Notjahre als reichliche Jahre [. . .]: Lebenshaltung und Hausarbeit Hamburger Arbeiterfamilien in der Weimarer Republik". in Klaus Tenfelde (ed.), Arbeiter im 20. Jahrhundert (Stuttgart, 1991), pp. 200-240, and "Wir werden alt vom Arbeiten': Die soziale Situation alternder Arbeiterfrauen in der Weimarer Republik am Beispiel Hamburgs", AfS, XXX (1990), pp. 247-296, and "Changer Chaque Jour de Travail: L'Emploi des Ouvrieres de Hambourg Dans les Années Vingt", Bulletin Centre Pierre Léon d'histoire économique et sociale, 2-3 (1994), pp. 23-35.

${ }^{21}$ These women Here chosen with the help of an extensive biographical questionnaire to cover the broadest possible range of life patterns and experience. I began with open biographical interviews. After analyzing the results, I conducted structured interviews with some of the women, and twenty-seven particularly rich interviews were transcribed as literally as possible into standard German. On methodological approaches and problems see Hagemann, Frauenalliag, pp. 20ff., and '“'Ich glaub' nicht, daß ich Wichtiges zu 
In working-class households, daily housework encompassed diverse tasks. The four most important functions were feeding the family, producing and maintaining clothing and linens, cleaning the home, and tending to the physical and, at the same time, psychological well-being of family members. The extent of housework depended upon a number of factors: alongside income level and housing situation, family size and composition and stage in the family cycle were particularly important. Hence it is impossible to analyze everyday housework in the working-class household and I shall limit myself to the example of one better-off working-class household. An account by Agnes A. (born 1898), the daughter of a Social Democratic skilled worker who told me her life story in a series of interviews, giving detailed descriptions of the working and living conditions in her parents' home and in her own family, will form the centerpiece of my investigation. ${ }^{22}$ I have chosen this example for two reasons. Firstly, the better-off urban working class in the Weimar Republic, with its relatively secure living conditions and correspondingly stronger orientation towards upward mobility, was among those groups of workers who were relatively open to social and economic rationalization efforts as the expression of an "up-to-date and rational" way of living and working, and one may thus expect them also to have been more inclined than other segments of the working class to respond positively to the idea of household rationalization. Secondly, the way in which Agnes A. describes her life, implicitly and explicitly comparing the living and working conditions in her parents' home with those in her own family, makes visible existing generational differences. The younger generation of the better-off working class, who started families in the 1920s and 1930s, represented the first generation of workers who, given a stable income, sought to achieve "modern" ways of living and consumption. ${ }^{23}$ Using the example, which I will introduce in more detail shortly, I will first describe the regularly recurring, particularly laborand time-intensive household chores, then analyze how girls learned these domestic tasks and the norms and standards associated with them and, finally, reflect upon the limits of rationalization in the working-class household.

\section{An average working-class family}

Franz and Frieda $\mathrm{H}$. lived with their two daughters Agnes and Paula (born 1900) in a Hamburg tenement neighborhood inhabited by many

erzählen hab' [. . . ] : Oral History und historische Frauenforschung", in Herwart Vorlănder (ed.), Oral History. Mfändlich Geschichte. Acht Beiträge (Göttingen, 1990), pp. 29-48; Shema Berger Gluck and Daphne Patai (eds), Women's Words: The Feminist Practice of Oral History' (New York and London, 1991).

2 Interviews with Agnes A., Hamburg, June 1981 and March 1984. All subsequent information on the $\mathrm{H}$. family comes from these interviews and the ten-page biographical questionnaire that Agnes A. filled out in March 1981.

25 See Hagemann, "Notjahre". 
working-class families. Franz $\mathrm{H}$. (born 1865), a skilled cabinet-maker, had relatively steady work as a piano-maker until his retirement and, in comparison to other workers, and according to his daughter's estimate, earned a good wage in the 1920s. Frieda H. (born 1870) had been in domestic service before her marriage. Her husband insisted that, as "his" wife, she give up all employment outside the home, for, like many skilled workers, he associated this with his masculine status as "breadwinner". For Franz H., this patriarchal attitude was by no means incompatible with his activities in the SPD and the Free Trade Unions. Frieda $\mathrm{H}$. was only allowed to boost the family income by taking in lodgers. Because the weekly household money that her husband gave her was never enough, in times of hardship she not only rented out the smallest room of their four-room $60 \mathrm{sq}$. m. courtyard fiat, but also regularly worked secretly as a cleaning woman. This open secret, one she shared with many neighborhood women, was a secret only to her own husband, who did not want to know. ${ }^{24}$

For Frieda $H$., who was also a member of the SPD, family planning and birth control were important means of regulating her own workload as well as the family's standard of living. Having a small number of children not only substantially reduced the necessary house and family work, but also gave women more financial leeway with the same family income. For this reason, women from the better-off working class began to limit family size relatively early, and their example was followed by other working-class women. This was reflected in the development of birth-rates, which had been sinking drastically since the end of the nineteenth century, particularly in the large cities. ${ }^{25}$

Like many working-class daughters, Agnes A. and Paula R. lived with their parents until they married. After elementary school, both attended a commercial school and began to work as office clerks. Their mother had supported her daughters' desires for occupational training and mobil-

\footnotetext{
24 See Agnes Martens-Edelmann, Die Zusammensetzung des Familieneinkommens (Eberswalde, 1931); Hagemann, "Notjahre".

${ }^{25}$ The birth-rate, i.e. the number of live births per 1,000 population sank on an average in Hamburg from 29 in 1900 to 11 in 1933. Of all working-class couples at this time, 29 per cent had one child, 20 per cent two, 10 per cent three and 12 per cent more than three children, 20 per cent were childless. For more detail see Hagemann, Frauenallag, pp. 196-204; for the general development in Germany, see John E. Knodel, The Decline of Fertility in Germany, 187I-1939 (Princeton, 1974); on population policy and the movement for birth control and abortion rights in Germany, see Karen Hagemann (ed.), Eine Frauensache: Allagsleben und Geburtenpolitik (Pfaffenweiler, 1991); Anna Bergmann, Die verhutete Sexualität. Die Anfänge der modernen Geburtenkontrolle (Hamburg, 1992); Cornelie Usbome, The Politics of the Body in Weimar Germany: Women's Reproductive Rights and Duties (London, 1992); Atina Grossmann, "The New Woman and the Rationalization of Sexuality in Weimar Germany", in Ann Snitow et al., Powers of Desire. The Politics of Sexuality (London, 1984), pp. 190-211, and Reforming Sex: The German Movement for Birth Control and Abortion Rights, 1920 to 1950 (New York and Oxford, 1995); Robert P. Neumann, "The Sexual Question and Social Democracy in Imperial Germany", Joumal of Social Histon, 7 (1974), pp. 271-286.
} 
ity against the will of their father. ${ }^{26}$ The girls were also strengthened in their resolve by the Socialist Worker Youth of which they had long been members. In 1920, Agnes A. married and left her parents' home. Shortly before the birth of her son in February 1921, however, she separated from her husband and moved back home. Her mother took care of the baby while she worked, and in return she contributed part of her earnings to the family upkeep. In 1925 Agnes A. remarried. With her second husband, a construction worker, and her son she moved to a smaller city north of Hamburg and until 1933 the two of them ran a regional youth center together. Her second child was born in 1926 and a third in 1928. Her sister Paula R. only left home after her marriage in 1928.

Viewed against the background of my research on the Alltagsgeschichte (history of everyday life) ${ }^{27}$ of the Hamburg working class, the chosen example of the $\mathrm{H}$. family seems to me in many respects typical, not only of the Social Democratic milieu but of a large segment of better-off working-class families in Hamburg, especially those of the older generation who were born before 1900 and married during the Wilhelmine period. To be sure, at the end of the Weimar Republic about one-fifth of all apartments were new, having been built after 1919. Despite this intensive construction of public housing, however, most working-class families, like the $\mathrm{H}$. family, continued to live in older districts. They could not afford the high rents on the new apartments, which were on average 44 per cent higher than comparably-sized older flats. Most lived in so-called small or middle-sized apartments. According to the national housing census of 1927,36 per cent of all flats in the city were small apartments of one to three rooms, including the kitchen and tiny nonheatable store- or bedrooms. Fifty-seven per cent were middle-sized with four to six rooms, although two-thirds of these had only four rooms. Most working-class households lived in cramped conditions and the figure

\footnotetext{
${ }^{26}$ See Karen Hagemann, "Ausbildung für die 'weibliche Doppelrolle': Berufswinsche, Berufswahl und Berufschancen von Volksschülerinnen in der Weimarer Republik", in Karin Hausen (ed.), Geschlechterhierarchie und Arbeitsteilung. Zur Geschichte ungleicher Enverbschancen von Männer und Frauen (Göttingen, 1993), pp. 214-236.

27 On approaches to Alltagsgeschichte (the history of everyday life), see Alf Lüdtke (ed.), Alltagsgeschichte. Zur Rekonstruktion historischer Erfahrungen und Lebensweisen (Frankfurt a. Main and New York, 1989), esp. Dorothee Wierling, "Alltagsgeschichte und Geschichte der Geschlechterbeziehungen: Über historische und historiographische Verhaltnisse", pp. 169-190; David Crew, "Alltagsgeschichte: A New Social History "From Below"?". Central European History (hereafter CEH), 22 (1989), pp. 394-407; Eley Geoff, "Labor History, Social History, Allagsgeschichte: Experience, Culture, and the Politics of Everyday - A New Direction for German Social History?", Journal of Mlodern History, 2 (1989), pp. 297-343. On the methodological problems of approaches using experience in the wake of the "linguistic turn" taken by feminist history see, most recently, Kathleen Canning, "Feminist History After the Linguistic Turn: Historicizing Discourse and Experience"; SIGNS, 19 (1994), pp. 368-404, esp. 368-384.
} 
of 1 or 1.3 persons per room, as in the case of the $H$. family, was not unusual. Twenty-five per cent of all Hamburg apartments were considered "densely occupied" or "overcrowded" by the 1927 national housing census, i.e. they were inhabited by more than one person per room. ${ }^{28}$

The terrible shortage of cheap small and middle-sized flats in the 1920 s, particularly in large cities, meant that many working-class families had to make do with extremely crowded living conditions. Their apartments were also frequently run-down, with serious structural defects. Most had no amenities, with bathrooms a rarity in the small apartments of Hamburg's tenement districts. Few working-class households in the inter-war period could afford such technical aids ${ }^{29}$ as electric or gas stoves, refrigerators, washing machines, water heaters or vacuum cleaners. ${ }^{30}$ In most working-class families, all family life took place in the kitchen. The $\mathbf{H}$. family also spent most of their time in the kitchen, which was the largest room in the flat, next to the parlor, which was only used on special occasions. In the small, overcrowded and run-down tenements, without amentities or appliances, housework was truly a labor of Sisyphus. Taking in a lodger further increased many women's

23 See Hagemann, Frauenalltag, pp. 51-89, esp. 70ff.; on architecture, housing conditions and housing policy in the Weimar Republic more generally, see Tilmann Buddensieg (ed.), Berlin 1900-1933: Architecture and Design (New York and Berlin, 1987); Barbara Miller Lane, Architecture and Politics in Germany, 1918-1945 (Cambridge, 1968); Schildt and Sywottek, Massenwohnung, pp. 127-287; Ulfert Herlyn, Adelheid v. Saldern and Wulf Tessine (eds), Neubausiedlungen der 20er und 60er Jahre: Ein historisch-soziologischer Vergleich (Frankfurt a. Main and New York, 1987); Michael Ruck, "Der Wohnungsbau Schnittpunkt von Sozial- und Wirtschaftspolitik: Probleme der offentlichen Wohnungpolitik in der Hauszinssteuerăra (1924/25-1930/31)", in Werner Abelshauser (ed.), Die Weimarer Republik als Wohlfahrtsstaat: Zum Verhältnis von Wirtschafis- und Sozialpolitik in der Industriegesellschaft (Stuttgart, 1987), pp. 91-123; Peter-Christian Witt, "Inflation, Wohnungszwangswirtschaft und Hauszinssteuer: Zur Regelung von Wohnungsbau und Wohnungsmarkt in der Weimarer Republik", in Lutz Niethammer (ed.). Wohnen im Wandel: Beitrage zur Geschichte des Alltags in der bargerlichen Gesellschaft (Wuppertal, 1979), pp. 385-407; Saldem, Sozialdemokratie, and "The Workers' Movement and Cultural Patterns on Urban Housing Estates and in Rural Settlements in Germany and Austria during the 1920s", Social History, 15 (1990), pp. 346ff.; D.P. Silvermann, "A Pledge Unredeemed: The Housing Crisis in Weimar Germany", CEH, 3 (1970), pp. 112-139.

20 On the development of household technology in Germany, see Karin Hausen, "Große Wasche. Technischer Fortschritt und sozialer Wandel in Deutschland vom 18. bis 20. Jahrhundert", Geschichte und Gesellschaft (hereafter GG), 13 (1987), pp. 273-303, esp. pp. 290ff.; Orland, Haushalts Träume, and Wäsche waschen: Technik- und Sozialgeschichte der häuslichen Wäschepflege (Reinbek b. Hamburg, 1991); Sybille Meyer and Barbara Orland, "Technik im Alltag des Haushalts und Wohnens", in Ulrich Troitzsch and Wolfhard Weber (eds), Die Technik: Von den Anfüngen bis zur Gegenwart (Braunschweig, 1982), pp. 564-583; Herrad U. Bussemer et al., "Zur technischen Entwicklung von Haushaltsgeräten", in Tornieporth, Arbeitsplatz, pp. 116-127.

${ }^{30}$ In 1932, for example, only 2,700 electric stoves had been installed in all of Hamburg. See HEW. Strom fä Hamburg - gestern, heute, morgen (Hamburg, 1982), p. 28. See Frauke Langguth, "Elekrizitat in jedem Gerăt - Elektrifizierung der privaten Haushalte am Beispiel Berlins", in Orland, Haushalts Träume, pp. 93-102. 
workload since, at least in the case of male boarders, it was customary for the housewife (for a small payment) to take over a portion of the tasks necessary for reproducing their labor power. Frieda $\mathrm{H}$. also cooked and washed for her boarders. In 1927, 25 per cent of all Hamburg tenants had boarders. Of these, 19 per cent had a three-room apartment, and 68 per cent a four- to six-room apartment. Most people only shared their apartments out of financial necessity. Taking in lodgers was an expression of economic hardship and should be regarded as a widespread form of female employment. ${ }^{31}$

Like Frieda H., many working women were compelled by insufficient family income to take up some form of paid employment. According to the national occupational census of 1925,22 per cent of workers' wives were in full-time employment. ${ }^{32}$ The proportion of fully-employed wives among all female employees rose continuously in the first decades of this century, in Hamburg as in Germany as a whole. According to the national occupational census, in 1907 only 9 per cent of all employed women in Hamburg were married. By 1925 the figure had risen to 16 per cent and by 1933 to 20 per cent. ${ }^{33}$ At that period, 54 per cent of all fully-employed married working-class women in Hamburg had children. Their biggest problem was finding someone to care for them during working hours. In Hamburg, as elsewhere, there were far too few day-nurseries, kindergartens and after-school facilities. Demand far outstripped supply, and women had to seek individual solutions. As in the case of the $\mathrm{H}$. family, grandmothers or other older female relatives frequently tended the small children of women in full-time employment in exchange for financial support. Not least because of their children, most working-class wives would have contributed to the family income through hourly work on the gray labor market such as sewing, cleaning and laundering or by taking on outwork. This was the form of employment they could best combine with their domestic and familial duties. ${ }^{34}$

\footnotetext{
31 Hagemann, Frauenalliag, pp. $73 f f$.

${ }^{12}$ Annemarie Niemeyer, Zur Struktur der Familie: Statistische Materialien (Berlin, 1931), pp. 111 and 115.
}

${ }_{33}$ See Hagemann, Fratcenallag, p. 28 . On the development of women's employment in Germany more generally, see also ibid., pp. 353-165; Renate Bridenthal, "Beyond Kinder, Kulche, Kirche. Weimar Women at Work", CEH, 6 (1973), pp. 148-166; Stefan Bajohr, Die Halfte der Fabrik. Geschichte der Frauenarbeit in Deutschland 1914-1945 (Marburg, 1979): Barbara Franzoi, At the Very Last She Pays the Rent: Women and German Industrialization, 1871-1914 (Westport, CT, 1985); Karin Hausen, "Unemployment Also Hits Women: The New and the Old Woman on the Dark Side of the Golden Twenties in Germany", in Peter D. Stachura (ed.), Unemployment and the Great Depression in Weimar Germany (London, 1986), pp. 273-303; Susanne Rouette, Sozialpolitik als Geschlechterpolitik. Die Regulierung der Frauenarbeit nach dem Ersten Weltkrieg (Frankfurt a. Main and New York, 1993); Annemarie Troger. "The Creation of a Female AssemblyLine Proletariat", in Bridenthal et al., Biology, pp. 237-270.

4 See Hagemann, Frauenalliag, pp. 419-428; see, more generally, Gabriele Wellner, "Industriearbeiterinnen in der Weimarer Republik: Arbeitsmarkt, Arbeit und Privatleben 1919-1933", GG (1981), pp. 534-554. 
Everyday housework

Agnes A. describes in detail the scope and sequence of everyday housework, constantly comparing her mother's work to her own. In her account, recollections of daily life in her parents' home usually blend seamlessly into those of life in her own family. Her mother's housework, with which Agnes $A$. and her sister began to help at an early age, is viewed in retrospect as a norm-setting model for work in her own household, which she depicts as being the same. This description of everyday domestic life spanning two generations makes clear how little the household chores performed by working women changed in the first half of the twentieth century. It was not until the 1950s that household technology made significant inroads into working-class homes in the Federal Republic of Germany, bringing about a significant transformation in housework. ${ }^{35}$ It seems to me that Agnes A.'s account is trying to express precisely this persistent sameness of housework in the workingclass milieu, which resisted all efforts at rapid modernization. At the same time, however, it also demonstrates how, slowly and over a period of many decades, the ideas of housing reform and household reform successfully won over even those women who, like Agnes A., had originally viewed them with a sceptical or negative attitude. Today she, too, sees herself as a housewife who does her work in a "modern" and "rational" way, and she depicts the housework of yesteryear from this perspective. Her account describes, with critical distance, the earlier practice of housework which - and she is conscious of this - obeyed different values and norms (which she deems "old") than her own later everyday life as a housewife. At the same time her account not only demands recognition for the hard work that her mother and she, like many other working women, had performed in the household, but also for the specific material and social conditions, and thus the specific logic of the norms and values, that underlay these achievements. In the interview she ties her changing attitude towards household reform directly to the changing conditions under which she performed housework, particularly the clear rise in living standards since the 1950 s, which enabled her to purchase labor-saving household technology. From her current perspective, she views this "technological revolution" in housework as an important result of the household rationalization propagated since the 1920s.

Agnes A. begins by describing the housewife's daily routine:

My mother, and later I myself, got up very early, between 5 and 6 a.m., cleaned the cold ashes out of the stove and lit it with kindling and paper. The first thing she did was to make coffeesubstitute and sandwiches for Father. Mother also got his breakfast ready. He had to leave the house at seven, or sometimes

3s See Meyer and Orland, Technik, pp. 564-583; Michael Wildt, "Das Ende der Bescheidenheit. Wirtschaftsrechnungen von Arbeiternehmerhaushalten in der Bundesrepublik Deutschland 1950-1963", in Tenfelde, Arbeiter, pp. 573-610, esp. pp. 601ff. 
even six o'clock. While we were still going to school, Mother woke us up after Father had left. She fixed us breakfast too - bread with jam and milk - and helped us make our sandwiches for school; we had either artificial honey or caraway cheese. Later, after we started working, we got up shortly after Mother and helped her with the morning chores.

After we were all out of the house, around 7 or 8 o'clock my mother, like most housewives, started to tidy up, airing the eiderdowns - for at least two hours - then making the beds and cleaning the apartment. First she swept all the rooms and the kitchen, then she washed the floors. She did that every day except for the two washing days and Sundays. Once or twice a week she also waxed the floors. She washed and waxed the floors on her hands and knees, reaching into every corner. We women were much more particular then than nowadays. Then she did at least a superficial dusting. The knickknacks, which we, too, had sitting around everywhere, were particularly impractical. They were real dusttraps. Once a week she gave them a thorough dusting. After doing all this the housewife had to think about shopping and cooking. We couldn't keep fresh food very well so Mother, and later I myself, had to go out shopping every morning. After shopping she had to cook. Shopping took a least an hour every day. Lunch had to be on the table between 1 and 2 o'clock when the children came home from school. After lunch the dishes from both breakfast and lunch had to be washed. This was done in the two basins that pulled out from under the kitchen table. It was quite a production. The dishes were sorted, wiped out with newspaper to clean off the bits of food, pre-rinsed, washed, rinsed again, dried and put away. And all without running warm water! We used soda instead of soap.

While we were still in school, Mother helped us with our homework after doing the dishes. We worked at the kitchen table and she sat with us, darning socks or sewing, or stood at the ironing board, all the while making sure that we did our work properly. Afterwards it was time for her to start thinking about making dinner for Father, who came home from work between 6 and 7 o'clock. He expected that she would at least cook some potatoes or vegetables fresh for him. He also wanted her to make a fuss over him after work. As long as we were in school, she also made special food for us children in the evenings, usually fried potatoes. Later, when my sister and I had jobs, we all ate a hot evening meal together. It was a great help for us both as working women that mother handled most of the housework [...] After dinner the dishes had to be washed again, and we helped out. Then there was more darning and sewing to be done $[. . .]^{36}$

This daily routine reveals the extent to which the organization and timing of housework revolved around the husband's work schedule and the children's school or workday. Most housewives seem to have tried to accommodate their needs. In general, the man's working hours set the rhythm of family life and with it of housework. Franz $\mathrm{H}$. was not the only husband who believed it his due as "chief breadwinner and head of the family" to have breakfast made before he left and a warm

36 Agnes A., March 1984. All subsequent quotations are also taken from this interview. 
meal, quiet and relaxation after he came home. ${ }^{37}$ In this ritualized division of time, and of the various tasks performed, and/or claims made, within the family household, the gender-specific and generational hierarchy in the working-class family was symbolically demonstrated anew every day and at the same time created through interaction.

Over and above these daily chores there were other household tasks that had to be accomplished on a weekly or monthly basis. Agnes A. explains:

Mondays and Tuesdays were wash-days, Wednesdays and Thursdays were for the cleaning chores that were only done once or twice a week, Thursdays and Fridays were for ironing, and on Friday evening or Saturday morning the weekend shopping was done. Saturday afternoon we took our baths, and food had to be prepared for Sunday. Then there were the chores that were done less frequently, cleaning the stairwells every two weeks, washing the windows every two to three weeks. In the spring and fall our summer or winter clothes had to be mended. From June to October we put up a lot of preserves. Before Christmas there were holiday preparations. All holidays and celebrations made a lot of extra work [...]

Food preparation, the production and maintenance of clothing and linens, and house-cleaning took the lion's share of time in the housewife's daily and weekly routine. Food preparation for the family was the most time-consuming activity. Agnes A.'s account makes clear how much more time this took in a household without refrigerator, freezer, or gas or electric stove. It began with shopping: all perishable products had to be purchased daily in small amounts, and a good deal of time went into comparing prices. In order to buy cheaply, Frieda H., and later her daughters as well, became members of a consumer cooperative. There they did their big weekly shopping on Friday, which was pay-day. Frieda $\mathrm{H}$. bought eggs and bacon as well as fruits and vegetables from small traders who every week took their carts from courtyard to courtyard, selling fresher and cheaper wares than any shop.

Shopping was very time-intensive, to be sure, but it also afforded working-class housewives many opportunities for communication. Sidewalks and courtyards, shops and markets were the central meeting-places for the community of proletarian housewives. Here they exchanged the latest news, tips and advice while they shopped. Women celebrated the big weekend shopping as a kind of public holiday, as Agnes A. recounts:

Shopping on Friday evening or Saturday morning was always a little holiday alleviating the monotony of the daily round for the women of our "terrace" [a specific form of courtyard]. They all appeared at the vegetable seller's and shopkeepers' with freshly-starched and ironed, usually white aprons. If one showed up not looking so clean and neat the others considered her a slut $[\ldots]$

37 See Marie Baum and Alix Westerkamp, Rythmus des Familienlebens: Das von der Familie täglich zu leistende Arbeitspensum (Berlin, 1931), pp. 99ff. 
There they exchanged the latest news [... ] Our courtyard was, like so many others, a village. Everybody knew everybody else, some of them were even related by blood or marriage [...]

The visible symbol of this weekly "holiday", one that served to mark social boundaries and exclusion, was the "best apron". Through her apron, a working-class woman could demonstrate for all to see her status as a "good", i.e. a "clean and orderly" housewife. In her memories, Agnes A. emphasizes the symbolic significance of the apron, which for housewives was much more than merely a useful article of clothing: "A woman who didn't wear an apron at home was not a woman. The proper apron was, so to speak, the symbol of the housewife [...]"

Alongside shopping, the proper storage of purchases, the preparation of food and washing dishes were all part of the work of feeding a family. On the whole, standards of nutrition had improved markedly, for working-class families as well, since the turn of the century. In the inter-war period a lighter, more nutritious and more diversified diet (meat, white bread, fruit, vegetables, and milk) tended to replace the heavy, hard to digest and monotonous fare of years gone by (rye bread, potatoes, legumes). In times of hardship, however, less well-off households often had to return to "poor people's food": potatoes and legumes..$^{38}$ Alongside rising living standards, another influence on dietary habits was nutritional science, the results of which were conveyed to working women in the 1920 s through magazines, cookbooks, household advice manuals and home economics classes. ${ }^{39}$ In everyday life, however, few working-class housewives will have had the leisure to devote themselves to the more elaborate culinary arts suggested there. As Agnes A. emphasizes, the preparation of nutritious but above all cheap food remained their chief concern. Diet, like all other areas of household management, was still subject to a strict regime of thrift, even in the inter-war period. The question "How can I save money in the home?" remained a central one. Hence women continued to buy as cheaply as possible, made many things themselves and recycled rather than discarded them. During the Weimar Republic, consumption had, in general, become more strongly market-oriented than it had been at the turn of the century, but even in the better-off segments of the working class

\footnotetext{
38 See Hans-Jürgen Teuteberg, "Der Verzehr von Nahrungsmitteln pro Kopf und Jahr seit Beginn der Industrialisierung (1850-1975): Versuch einer quantitativen Langzeitanalyse", AfS, XIX (1979), pp. 331-388, esp. 34t-384.

${ }^{39}$ On the development of nutritional science, see Hans-Heinz Eulner, "Die Lehre von der Emährung im Universitätsunterricht", in Edith Heischkel-Artelt (ed.), Emähnung und Emährungslehre im 19. Jahrhunderr. Vorträge eines Symposiums am 5. u. 6. Januar 1973 in Frankfurt a.M. (Göttingen, 1973), pp. 76-98; Hans Jürgen Teuteberg and Günter Wiegelmann, Der Wandel der Nahrungsgewohnheilen unter dem Einfuß der Industrialisiening (Göttingen, 1972), and Unsere tägliche Kost: Geschichte und regionale Prägung (Münster, 1986), pp. 63-281, 310-334 and 345-370.
} 


\section{Of "Old" and "New" Housewives}

the trend towards mass consumerism was interrupted by continuing dependency on developments in the economy. Supply crises, inflation and mass unemployment also restricted the way of life of these workingclass groups to a greater or lesser degree. The primary "buffers" that allowed families to cope with income fluctuations caused by market forces were women's domestic provisions for the family, and, mainly in emergency situations, their earned income. During the entire inter-war period recourse to these traditional forms of proletarian crisis management remained part of the family "emergency economy".

The production and maintenance of clothing and linens took up a great deal of time. A large proportion of clothing, particularly for women and children, was sewn at home. What little clothing and linens were available had to be treated with the utmost care. Everything was constantly being altered, darned and mended. "Make new things out of old", was the operative motto. Agnes A. reports:

We made most of our own clothes. Old articles of clothing were altered and adapted to the new fashion. We did the work on our foot-pedal sewing machine [...] The only things we bought were Father's suit and later, our overcoats [...] The work I hated most was darning and knitting socks, but mending, knitting and crocheting were pretty awful too [...] We leamed all that at school, in sewing class [...]

Because most people had very little clothing and linen, they had to wear everything longer and it was correspondingly dirty when wash-day came around. This made cleaning a more arduous process. Washing and ironing without technical appliances to make work easier were particularly labor- and time-intensive chores and were spread out over several days. How often women washed depended mainly upon the size of the family and how much clothing was available. In general, the "big wash" was done every one to three weeks. ${ }^{4 l}$ Agnes A. recalls:

My mother, and later I myself, did the wash every week. On Monday we prepared the laundry, Tuesday was wash-day, Friday we ironed. In this way three days of the week were already taken up with plenty of work [...] Even after we started going out to work we had to help Mother with the wash. What a chore it was $[\ldots]$

Agnes A. remembers the "big wash" down to the smallest details. She particularly emphasizes the physical exertion involved in soaking, boiling, scrubbing, rinsing and starching the laundry by hand. The only aids were a washing vat on the coal stove, wooden tongs, a tin tub on a three-legged wooden stool, a washboard, a laundry brush and a wringing-machine. Most laundry was dried in a drying-room. Everything that had to dry particularly quickly, however, was hung up in the

"See Hagemann, "Notjahre".

4t See the instructions for washing in Meyer, Hauswirtschaftslehre, pp. 143ff. 
kitchen, usually from lines pulled across the ceiling. When the laundry was dry, it was carefully laid out and stretched, sprinkled with water and then ironed with a flat-iron, another time-consuming procedure. Agnes A. reports that she and her mother could only afford electric irons in the 1930s. Many working women considered the "big wash" the most arduous part of housework.

Housecleaning also took up a good deal of time. The scale and sequence of cleaning chores in Agnes A.'s description of her mother's daily routine correspond to the norms propagated by popular (old and new) household advice manuals. Certainly Frieda $\mathrm{H}$. and her daughter will not always - perhaps only rarely - have managed to live up to the internalized norms and standards in the way described by Agnes $A$. Even in the better-off working-class milieu, presumably not all housewives were so orderly and clean. Neither, however, do Agnes A. and her mother appear to have been an exception. Other women from the Social Democratic milieu whom I interviewed supported this account. All interviews refer to the fact that although the amount of cleaning was strongly shaped by milieu-specific norms and standards, these also had a material basis, which Agnes A. also emphasizes. In her account she seeks to make clear that many household chores that may appear superfluous today were necessary back then

because the apartment was too small to air properly. Everything got dirtier much more quickly than it does today, with the overcrowding and coal heating. It makes a lot more dirt when you have five or six people living in a $60 \mathrm{sq} . \mathrm{m}$. apartment, which was the case later when $I$ and my son moved back in with my parents.

A closer look at everyday housework in the working-class milieu underlines this corrective to hasty judgements. The condition, furnishings and number of occupants of an apartment, as well as how, and how intensively, the apartment was used, significantly influenced the amount and kind of cleaning required.

The twice-yearly fall and spring "big cleaning", which was a must in "respectable" working-class households, was particularly timeconsuming. "Modern" household advice manuals recommended that housewives save time by restricting themselves to one big "spring cleaning". 42 "Good housewives" felt compelled to ignore this advice, however, as Agnes A. explains:

Actually, I found the big fall cleaning, at least, superfluous. Once a year would have sufficed [...] The whole place was turned upside down during the big cleaning, which usually lasted an entire week. The men fled to the nearest bar. For us women it was an awful lot of work. But it was hard for us to escape the pressure. The women neighbors kept an eye on each other in our "terrace"

42 See ibid., pp. $141 \mathrm{ff}$. 
and everybody knew what you were doing, or not doing. If we hadn't done a big cleaning twice a year they would have viewed us as sluts. And we didn't want that, nobody did [...]

For many women, a good "reputation" in their own women's network of relatives, friends and neighbors weighed more than all the sage advice of the proponents of household rationalization. This reputation, with which their status as "good housewives" stood and fell, was a decisive determinant of their position in, and with it, of the extent of support they could expect from the women's network, which played a crucial role in mastering the vicissitudes of everyday life. One's "reputation" as a "good housewife" depended not least upon apparently functionless ritualized symbolic actions such as the wearing of a particular apron for a particular occasion, or the yearly public show of the "big cleaning". All housework that was subject to a measure of public control was important here. One could tell a "good" housewife, among other things, by the "clean and tidy" clothing worn by family members when they went out, by the shining windows and freshly-washed curtains and by the "parlor" that was always ready to receive guests. Also important were those household chores that had to be performed for the whole building, such as the regular and thorough cleaning of the stairwells. By maintaining these norms and standards, a housewife demonstrated to her women's network that she was trustworthy and reliable. Through reciprocal social control, working women themselves thus saw to the dissemination of specific norms and standards of household management. Even among younger working-class women during the Weimar Republic, these norms and standards still corresponded much more to the old model of the "thrifty, clean and tidy" housewife than to the new model of the "rational and efficient housewife". It was mainly because of scarce economic resources, which repeatedly compelled housewives to depend not only on the traditional "regime of thrift", but also on mutual aid in the neighborhood women's social network, that the new ideas could not take root. For a "good housewife" it was, more than a "point of honor" to follow milieu-specific norms and standards, at least when performing publicly visible housework. ${ }^{43}$ The social significance of the women's network made it necessary for their very existence. When women did their everyday housework according to the norms, they also won social recognition. The fulfillment of these norms enhanced the status of housework: it assured women that they were "good" housewives and not "sluts", and gained them the recognition of mothers and aunts, friends and neighbors. This recognition boosted their self-confidence and

${ }^{43}$ For the importance of the women's network in the British working-class milieu, see Roberts, A Woman's Place, pp. 183-192; Ellen Ross, "Survival Netw'orks: Womens's Neighbourhood Sharing in London before World War I". History Workshop 15 (Spring 1983). 
helped them to bear the patriarchal ambivalence that so many workingclass men exhibited towards housework. Looking back, this is how Agnes A. describes this ambivalence:

A worker who didn't marry an efficient housewife was out of luck. And most workers recognized that. The men's ambition was to marry a capable woman, to have her at home. But they still wanted to be the boss. That led to a lot of quarrels [...] In order to maintain their position in the family, the men had to consider everything women did inferior, to keep their self-esteem low. What I could never understand is why these men really never appreciated housework even though they depended on it. What in the world would they have done without wives who did nothing but work?

All working women realized the importance of everyday housework, however denigrated by their male kin, for the family's way of life. As "good" housewives, they could at least count on the women's network to recognize the work they did.

\section{Learning the norms and standards of housework}

Most working-class daughters learned the skills that went into making a "good housewife" primarily from their mothers. In most cases, they began to help in the household at an early age. Agnes A. recalls:

I acquired most of my knowledge of the work that needs to be done around the house from my mother, who had been a housemaid and a cook. My father, who received a strict, Prussian upbringing, was also a stickler for order, cleanliness and correctness. My parents had the attitude that their daughters couldn't begin learning about housework early enough, so they could get on in later life. We already had our own special chores when we were seven or eight years old. My sister had to help clean the kitchen every day. It was her job to wash the tile floor, and to keep the tiles and the brass fittings shiny. I had to help Mother clean the other rooms. It was my job to clean the floors and furniture and dust [...] On Sundays Father checked whether everything was shiny [...] These household chores always felt like a terrible burden to us. Our father was especially strict, though. As I recall, all our girlfriends from school had to help out at home at that age too.

As a child Agnes A. may have experienced helping with household chores as a burden, but when she became a mother herself she also made her children help out at home. In the Weimar period this appears to have been the rule in working-class families once the children had reached school age. Children most frequently began by running errands and doing the shopping. Later, these occasional chores were supplemented by regular ones, such as looking after younger siblings, cleaning the kitchen, drying the dishes and helping with the big wash. At first, not much difference appears to have been made between the sexes. As boys got older, though, they were expected to help less with the housework. Instead they found paid employment alongside school and contrib- 
uted to the family support in this way. Girls had more housework to do as they grew up. In general, children in working-class families were expected to help out more than those in the families of salaried employees or civil servants. Most working-class children seem to have regarded household chores as a necessary and natural duty, one they fulfilled in the knowledge that they were lightening the burdens of their overworked mothers. ${ }^{4}$ By helping out at home, working-class girls did more than just learn the many tasks involved in housework and adopt their mothers' norms and standards. At the same time, they learned that housework was primarily "women's work" that male family members valued less than any kind of paid labor.

In the long run, the everyday norms and standards of housework were also influenced by years of systematic education and training on the part of the state, churches and middle-class associations that, since the mid-nineteenth century, had pursued the "hygienic civilizing" of working women. ${ }^{45}$ Like many working-class women, Frieda $\mathrm{H}$. and her daughters had largely internalized middle-class normative standards of hygiene and cleanliness and sought to live up to them in their own housework. The prerequisites for accepting these middle-class norms, and above all for putting them into practice, were time and money. In order to fulfill the demands made upon them, the living standards of a working-class family needed to be high enough so that the woman could devote a major portion of her labor power to housework.

Hence women from the better-off segments of the working class were the first to adopt middle-class norms and standards of household management. They were then followed by broader strata of women. In Hamburg, this development presumably received a substantial boost when compulsory home economics instruction was introduced into the elementary schools for girls in $1908 .{ }^{46}$ The city-state of Hamburg was, after Baden, the second German state to introduce such classes alongside the long-established needlework courses for elementary school girls. Such instruction was not made obligatory on a national level until 1939; before that it was up to individual states, provinces and towns to introduce home economics. In the Weimar Republic it became customary in elementary schools everywhere. According to Hamburg's 1912

\footnotetext{
4 See Margret Barth and Annemarie Niemeyer, Uber die häusliche Hilfeleistung von Kindern (Berlin, 1932), esp. pp. 9-35.

${ }^{45}$ See Ute Frevert, "The Civilizing Tendency of Hygiene: Working-Class Women under Medical Control im Imperial Germany", in John Fout (ed.), German Women in the Nineteenth Century: A Social History (New York and London, 1984), pp. 320-344.

${ }^{46}$ For what follows as well see Hagemann, Frauenallag, pp. 117-132, and "Hauswirtschaftsunterricht für Mädchen an Volks- und Berufsschulen", in Hans-Peter de Lorent and Volker Ullrich (eds), "Der Traum von der freien Schule": Schule und Schulpolitik in der Weimarer Republik (Hamburg, 1988), pp. 252-272; Gerda Tornieporth, Studien zur Frauenbildung: Ein Beitrag zur historischen Analyse lebensweltorientierter Bildungskonzeptionen (Weinheim and Basel, 1979).
} 
"Curriculum for Home Economics for Elementary School Girls", such instruction was intended to convey basic knowledge and housework skills. Girls were to be trained to be dutiful housewives capable of running their households with "thrift, order and cleanliness". Particular stress was laid on "economical household management"; the girls were supposed to learn how to manage on a shoestring budget. In Hamburg, girls in the last year of elementary school had four, and after 1926 three, hours a week of home economics instruction.

For the majority of elementary school girls, home economics training was intensified during the Weimar Republic by subsequent courses at the newly introduced girls' vocational schools, which they had to attend for eight hours a week. In 1919 further education had became compulsory on a national level both for all male and female domestic servants, unand semi-skilled workers and employees and unemployed girls between the ages of fourteen and seventeen. This instruction was based on the model of the "female dual role": pupils, largely from working-class families, were trained primarily for their future "main occupation of housewife and mother", and only secondarily for the phase of paid employment before marriage. This was reflected in the curriculum: aside from two hours of pre-vocational training the girls received instruction in home economics, needlework, health and hygiene, practical and theoretical aspects of childrearing, cultural studies, economics and social studies. The main objective of training at Hamburg's girls' vocational schools, as described in a book published in 1927 by the schools' teaching staff, was two-fold:

Apart from the simple practical training, which girls from all classes cannot be given at home, because their mothers either have not themselves had it, or cannot find the time for thorough instruction, [it also includes] investing the family with new meaning, by relating the work of the housewife and mother to our nation's deepest and most beautiful qualities of soul and mind."

In order to achieve this goal, vocational school pupils, and, since the introduction in 1926 of new guidelines for the Hamburg elementary schools, also elementary school girls, were to be trained in the spirit of the new ideas of household rationalization. Accordingly, the abovementioned book went on to say that:

The foundation of instruction (is) the work of the housewife as it has been passed down to women through tradition. Not [however] in the traditional sense of household management, which is satisfied with the simplest housework skills, possibly without any scientific basis or modern technology, but rather in the sense of consumer management, which uncovers the connections between the

47 Emmy Beckmann, "Bildungsaufgaben und Erzichungswerte der Mădchenberufsschulen". in Von dem Leben und der Arbeit unserer Allgemeinen Mfddchenberufsschulen in Hamburg, hg. v. Lehrkörper der Staatlichen Allgemeinen Gewerbeschulen für das weibliche Geschlecht (Hamburg, 1927), pp. 26-31, esp. p. 31. 
individual household and economic life more generally and makes the claims of the community through those of personal well-being and personal economic achievement. ${ }^{48}$

Instruction emphasized an introduction to "rational household management" on the one hand, and conveying new "scientific knowledge" about health and hygiene, particularly the care of babies and small children, household hygiene, and pedagogy on the other. "Cultural studies" was also considered particularly important, and was supposed to treat, among other things, issues of "home culture", family life and leisure activities. We can only speculate about the effects of this instruction, as the available sources are not explicit on this point. There are many reasons to believe, however, that reformed home economics instruction at the girls' elementary schools, but more particularly the training offered at the girls' vocational schools in the Weimar Republic played an important role in disseminating among girls and young women the "modern" model of a housewife who managed her work in a "rational" manner. Girls' acceptance of this model, like the impact on them of instruction in home economics, varied greatly according to the social milieu in which they grew up.

Agnes A., who belonged to one of the first groups of girls to participate in obligatory home economics classes at the Hamburg elementary schools, describes how this acceptance varied among girls of different backgrounds:

I can still remember home economics class very well [. . ] We both attended. We were especially proud of the white aprons we had to wear, with oven cloths on long ribbons. Many of the rules we were taught have remained with me [...] These rules of housework were really drummed into us so that we might never forget them. And it worked, too [...] I always liked home economics because I had brought the required love of order and system with me from home. Most of my fellow pupils thought it was stupid, though, because they regarded all the rules as superfluous. They also often came from working-class families with a lot of children where it was very hard to stick to these rules. They found them excessive because they had too much trouble getting by at home [... . ]

How girls reacted to home economics instruction depended mainly upon their home situations. Relatively secure economic circumstances, such as those of the $H$. family, seem to have been an important prerequisite for accepting the norms conveyed in the classroom, which could be applied to the girls' own household. Pupils who saw, on the other hand, that the content of their home economics lessons had little bearing on their own home situation tended to reject or at least be sceptical of the subject.

s Lilly Peters, "Unsere Aufgaben im neuen Schulhaus", in Von dem Leben und der Arbeit, pp. 18-22, esp. p. 19. 
In the Weimar Republic, many working women, especially those from a better-off milieu, had internalized the traditional middle-class expectations of household management to the extent that they no longer questioned them. Thus the "old" goal of training girls to be "thrifty, clean and tidy" housewives was apparently successful in the long run. As Agnes A. reports, "All of these many tasks and steps became a matter of course. A good housewife did them without thinking twice. We learned it from our mothers, that's what they taught us in school. We knew it from our employers' households [...] These norms had become second nature to us [...]".

\section{The limits of household rationalization}

Even in the better-off urban working-class milieu of the Weimar Republic, the norms and standards of everyday housework appear to have owed more to the old middle-class model of the "thrifty, clean and tidy" housewife than to the new model of a rational, "up-to-date" manager-housewife. This was particularly true of the generation of working women who, like Frieda $\mathrm{H}$., were already married during the Wilhelmine period, but presumably also for a large proportion of those who, like Agnes A., had started their families during the Weimar Republic. To be sure, working-class women were considered a chief target of the campaign for household rationalization. But even the intense Social Democratic propaganda on behalf of the "rationalized individual household" did not reach the mass of housewives. Agnes A. provides information on the possible causes:

We read about the rationalization of housework in the daily papers, in the [Hamburg] Echo. It was also discussed at SPD women's evenings. We also asked for things for our birthday, e.g. a girlfriend of mine gave me an oven-proof casserole of Jena glass. But we only asked for small household items. All the larger appliances were too expensive, we could only dream of them [... ] Most of the time-saving suggestions that came from architects and engineers were valuable, to be sure, but usually didn't consider the reality of the mass of housewives enough [... . We didn't rearrange our apartments; once we had furnished our places, that was it.

The most important reason for the sceptical and reserved attitude of most working women was clearly that the recommendations for household rationalization generally bore little relevance to everyday life in their homes. This applied both to the "rationalization" of working methods in the household and modernization of home furnishings and to the many small and large labor-saving devices suggested for purchase. With their time at a premium, working-class women, whether employed outside the home or not, were compelled to manage their households rationally anyway. Because of their family's low and often fluctuating 
income they had always had to make frugal use of money and material.9 In small working-class apartments, the problems of long distances or the functional placement of furniture did not arise. The majority of working-class housewives rejected the idea of a "clearing out" and "functional reorganization" of their homes, because for them the Victorian furnishings still common in the 1920s symbolized comfort and longed-for bourgeois prosperity. Most established working-class households could no more afford new furniture than modern household technology. ${ }^{50}$ Thus the vast majority of working women in the 1920 s presumably viewed suggestions for reforming their households as simply unrealistic. ${ }^{51}$

Women's skepticism and misgivings about recommendations for household rationalization were presumably intensified to a great degree by the specific norms and values that working-class women's social network used to measure a "good" housewife. As long as these women's networks remained intact, retaining their great significance for dealing with the cares and worries of everyday life, their influence on everyday housework seems to have been greater than all outside efforts at education. The decline in importance of these working-class women's networks beginning in the 1930s, and their extensive destruction during the National Socialist period, and more particularly during World War II, by a number of social and political factors, facilitated the adoption of new norms and standards.

Given the complexity of everyday life, however, criticisms of the propagated rationalization of housework did not necessarily mean that working women fundamentally rejected all of the concepts and achievements of household and housing reform. Most working-class housewives would doubtless have gladly purchased the new labor- and energy-saving houshold appliances; at the top of their unattainable wish lists were electric stoves, washing machines, refrigerators and vacuum cleaners. Many would have been happy to move into a comfortable new apartment and to use the amenities offered there, which usually included not only one's own bathroom and a kitchen with gas stove and hot water boiler, but frequently also fully automatic common laundry facilities with an ironing room and children's playground in the courtyard. The rejection of suggestions for household rationalization could also coexist unproblematically with a mental willingness to "rationalize" other areas of everyday

\footnotetext{
49 On the limits of household rationalization, see Hirdina, Hausarbeit, p. 48; Barbara Methfessel, "[.. .] entscheidend bleibt die Arbeitskraft der Frau: Zu den Grenzen der Rationalisierbarkeit und Technisierbarkeit der Hausarbeit", in Tornieporth, Arbeitsplatz, pp. 55-85; Nolan, Housework, pp. 571ff.; Gisela Stahl, "Von der Hauswirtschaft zum Haushalt oder wie man vom Haus zur Wohnung kommt", in Wem gehört die Welt? Kunst und Gesellschaft in der Weimarer Republik, ed. Neue Gesellschaft für Bildende Kunst (Berlin, 1977), pp. 87-108, esp. p 105.

so See Pr.FK.SPD 1927, pp. 358 and 366.

sl See Hagemann, Frauenalliag, pp. 111ff.
} 
life. Thus already in the 1920 s many working-class women like Frieda $\mathrm{H}$. and Agnes A. accepted as a matter of course the norms and standards being propagated as "up-to-date" in the fields of family planning and birth control, as well as infant nutrition and care. ${ }^{52}$

Everything points to the fact that the new model of the "rational" and efficient housewife, which was supposed to bridge class boundaries, met with a positive response only among a very small segment of working women during the Weimar Republic. These appear to have been mainly younger women from the better-off sections of the working class who were born after the turn of the century and married skilled workers. They belonged to the first generation of women who underwent intensive training to become "modern" housewives and mothers, training offered during the Weimar Republic not only by the elementary schools and girls' vocational schools, but also by schools of adult education, public health and social weifare institutions and home visitors. An important prerequisite for the acceptance of the new model of the housewife by these young working-class women was clearly the relatively prosperous living conditions of their newly-founded families. Their incomes were higher than those of many other working-class families, they usually had few children and often better housing. Apart from the families of salaried employees and civil servants, it was recently married, better-off working-class couples who benefited most from the achievements of public housing. Thus it was these couples who were the first within the working class to develop decidedly modern urban ways of consumption and living and a great willingness to "rationalize their everyday life"..$^{33}$

In the longer term - in the course of the 1930s but above all in the 1950 s - with rising standards of living, such a "modern" urban way of consumption and living also spread to broader segments of the working class. It not only brought more household technology into working-class homes, but also helped to spread the new model of the housewife. As many recent studies have shown, neither change meant less labor for women, but merely a shift of emphasis in the work done by housewives and mothers. Viewed in retrospect, the demands made upon women's household and family work grew substantially in the course of this development. Now women were expected not merely to keep their homes "clean and tidy", but also to manage them "efficiently and economically" while devoting more attention to their new duties as mothers and wives and, in addition, working to create the proper "home culture". Along with responsibility for the physical and emotional well-being of all family members they were also entrusted with the responsibility of ensuring that the family remained a functional and stabilizing institution within society. ${ }^{.4}$

52 See ibid., pp. 196-219.

${ }^{53}$ See ibid., pp. $79-86$ and 112; Hagemann, "Notjahr".

st See esp. Cowan, More Work for Mlothers. 